\title{
Development Of Augmented Reality code application on 3D Animation in Learning Procedure at School
}

\author{
Banne Ima Gasong ${ }^{1}$, Rufi'i ${ }^{2}$, Hartono ${ }^{3}$ \\ ${ }^{1,2,3}$ Educational Technology, PGRI Adi Buana University, Surabaya \\ ${ }^{1}$ Guru SMK Negeri 1 Dlangu Mojokerto Jawa Timur Indonesia
}

\section{Edcomtech}

Jurnal Kajian

Teknologi Pendidikan

Volume 6, No 1, April 2021

79-90

Submitted 30-04-2020

Accepted 10-05-2020

Corresponding Author

Gasong

imakarya2020@gmail.com

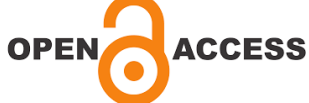

\begin{abstract}
The use of AR (Augmented Reality) technology in the world of education continues to increase. Android, as a booming trend, is currently taking part in adopting $A R$ technology. The ease and usefulness of Android-based AR technology can also be applied to the learning media development strategy. That spreads to the world community will also have an impact on students. Media Flyer Code as a marker on AR technology is applied to 3D Animation subjects. This study aims to determine the Augmented Reality Code Application's appropriateness, especially the effectiveness, attractiveness, and efficiency of media. This research and development product is in the form of a Flyer Code product that will be used as a code and APK file. Each Flyer Code has one content that is run on the android application. The augmented reality content contains 3D Animation Learning Procedure, and questions contain evaluation material.
\end{abstract}

Keyword: Flyer Code, Augmented Reality Code Application, Android, 3D Animation Learning Procedure

\section{INTRODUCTION}

The industrial revolution 4.0 began in the early 21 st century, marked by technology that reduces the distance between people. Humans everywhere can be easily connected. The special feature of the 4.0 industrial revolution is the marked era of everything connected to the internet. The transition from all aspects of life that used to be analogous to digital and connecting it to the wider world through the internet is a striking difference in this era. Thomas Cochrane expressed the same thing, the internet, which is very familiar with mobile devices, became a highly sought after commodity. The use of cellular devices, mobile phones have replaced traditional print-based paper media. Print media users are experiencing compilation, newspapers, and magazines, for example, because more users are developing flexible access on their mobile devices (Thomas Cochrane, 2017). The internet world penetrated people's lives, economy, society, politics, culture, and education. The technology also utilizes digital technology, such as Big Data, Cybersecurity, Autonomous Robots, Cloud, and Augmented Reality.

Digital technology, such as Big Data, Cybersecurity, Autonomous Robots, Cloud, and Augmented Reality, almost replaced the conservative analog world's role. One digital technology that is on the rise in AR (Augmented Reality) technology. AR, which was originally just technology in military simulation and the need to apply how to drive on the road with the appearance of really feeling the atmosphere on the road without disturbing other drivers, has now entered the world of education.

AR definition combines cyberspace into the real world technology that was once almost impossible to do. But increasingly, at present, AR technology is increasingly well known and used by the general public. According to that 
definition, $A R$ is a technique for displaying the environment of real objects that are boarded by virtual objects ( $\operatorname{Tan} Q$, Chang $W$, and Kinshuk, 2015).

Learners called students to act as target components of the learning process at school. Whereas the teacher acts as a facilitator of the deciding component of the learning process. The key determinant of learning objectives between teacher and student is students' needs, subjects, and roles. Often the students' needs are influenced by the environment and the age that follows. Based on the subjects contained in the curriculum instructions can be determined desired educational outcomes. The teacher himself is the main source of destination for students. One of the teaching tools used to help convey subject matter in the learning process is to use media. In the opinion of Strakova and Cimermanova, 2018, teachers can use technology, sophisticated computers, or new technology to deepen the learning experience in their classrooms. Educational media with technology have become increasingly diverse, which can be demonstrated by educational media in the form of games, simulations, virtual reality, and augmented reality (Knight \& Barbera, 2018).

The development of the world of technology, especially smartphones, is defined as smart phones that have made the hardware a necessity. Shifting the need for smartphones that were once only a means of communication and social media, every individual can not be separated from smartphones in everyday life. Android as the largest operating system vendor of smartphone software provides open space to use various applications that anyone can use. Various ages can use these applications, some applications are suitable for children, adolescents, and even adults. The applications are also various so that most of what we are looking for will get the city in one hand (Aguayo, Cochrane, \& Narayan, 2017).

The use of android technology in the world of education is already familiar. Some applications are easy to download. With no payment, the download process can also be carried out. Downloading an application in practice is like a purchase transaction. Some money or in the form of a quota must be exchanged with the application file capacity. This application file has an apk extension which is then installed on a mobile phone.

The use of android-based application media is one way to provide learning innovations for students. Something new and popular with the general public is expected to make students not experience boredom. By borrowing the term "kids now", children today, the world of education, especially the teacher's role as a facilitator should keep up with the times. The expected result is subject matter that can be delivered.

Teaching material is a set of information that students must absorb through fun learning. This shows that in the preparation of teaching materials students are expected to feel the benefits of teaching materials or material after learning it. Teaching material is a medium to achieve the desires or goals to be achieved by students.

Based on the above study, the term teaching material used in this study is a systematically compiled material / subject material used by teachers and students in learning 3-Dimensional Animation Techniques in Vocational Schools to achieve the expected goals. The feasibility of the media used for independent learning is an application suitable for use as a medium for independent learning (Mantasia \& Jaya, 2016).

Following current technology trends, education, explore AR technology, take advantage of the technology, and discover the advantages and positive impact of using $A R$ technology on education (Cheng, 2017). The paper of development of augmented reality code application that displayed in learning $3 \mathrm{~d}$ animation. AR technology allows learning outside the classroom both space and time of learning, thus creating an unlimited learning (Alkhattabi, 2017).

\section{METHOD}

In the development of learning tools needed a development model. Currently there are 3 research development models that can be used in the development of instructional media, namely models: 4D Thiagarajan (1974), Borg \& Gall (1996), and ADDIE Dick and Carry 
(1996). The development model in the study entitled Development of Augmented Reality Application Code on 3D Animation in Learning Procedures at School uses S. Thiagarajan model with known Define, Design, Develop, and Disseminate.

In the defining stage, a front-end analysis is carried out, an observation process to determine the description of the understanding and skills of students of Class XI Multimedia SMKN 1 Dlanggu on the subject of 3-dimensional animation techniques. Furthermore, the defining stage data is used in the next stage, namely the design stage. In the design stage the design of media selection is made to identify learning media relevant to the characteristics of the material. The choice of format in learning tools is intended to design or design learning content, selection of strategies, approaches, learning methods, and learning resources. The format chosen is one that meets the criteria of attracting, facilitating and assisting in learning.

Define stage is done by interviewing students and teachers to find out problems in learning. In the define stage, several steps are carried out to get a picture of the problem being faced. The determination of teaching materials used is the media that is loved by children today. Therefore the media used is media with facilities found on mobile phones. Interviews were conducted with a minimum of 5 students. Questions asked include the respondent's age, the ownership of an Android mobile phone, the number of hours of use in a day, the interest in a new application, and the comparison of learning preferences in class with independently using a cellphone. Student analysis includes the level of ability or intellectual development and skills of each child in the subject of 3-Dimensional Animation Techniques. Analysis is taken from the list of student grades on these subjects. In this stage the observations were made covering the value of academic ability (knowledge) and the value of skills.

The design stage aims to design learning media more effectively and efficiently to develop the product design based on data obtained from the define stage. The design stage is arranged based on the specifications of the learning objectives and student analysis, and then the questionnaire instrument grids are validated using the flyer code media product validation. The selection of media conducted at this stage of research is the media that is appropriate to students' needs based on the results of the needs analysis. An important point in the media selection stage is learning that promotes independence. With personal ownership of the handphone, the researcher chooses and sorts the appropriate media containing the 3 Dimension Animation Technique tutorial.

The development stage is the stage to produce a product that implements the activities carried out previously. This stage aims to produce a product in the form of a flyer code media using augmented reality based on Android that is feasible to use. The steps include expert validation and development trials. Expert validation is in the form of an assessment conducted by experts / practitioners of learning tools. The assessment includes the effectiveness, attractiveness, and efficiency of the screen display format, language, illustrations and content. The development test was conducted on 3 multimedia teachers as co-authors of the class XI Multimedia and 30 students.

Validation was carried out by several parties, namely the media expert evaluation questionnaire and learning design / design and content experts / learning material used as assessment material for the development of the media created. Validation using interviews and questionnaires with 4 scale indicator answer options, shown in table 1.

Table 1. Scale Indicator Answer Options

\begin{tabular}{cccc}
\hline 1 & 2 & 3 & 4 \\
\hline $\begin{array}{c}\text { Not } \\
\text { suitable }\end{array}$ & $\begin{array}{c}\text { Quite } \\
\text { appropriate }\end{array}$ & Corresponding & $\begin{array}{c}\text { Very } \\
\text { appropriate }\end{array}$ \\
\hline Not clear & Quite clear & Clear & Very clear \\
\hline $\begin{array}{c}\text { Less } \\
\text { attractive }\end{array}$ & $\begin{array}{c}\text { Quite } \\
\text { interesting }\end{array}$ & Interesting & $\begin{array}{c}\text { Very } \\
\text { interesting }\end{array}$ \\
\hline
\end{tabular}

Validation data from media experts, material experts, peers, and students who have been collected is done on average for each component in question. These components include effectiveness, attractiveness, and 
efficiency.

Questions for media experts and concurrent learning design experts as much as 8 points effectiveness include media display, media content on learning strategies, text clarity in each scene, visual clarity / image in each scene, video clarity in each scene, audio clarity in each scene, display animation of each scene, and the presence of buttons to move each scene. 9 points attractiveness questions include the choice of media as interactive media, the attractiveness of learning, the attractiveness of learning organizing technology, the attractiveness of message design on acceptance of learning media, the attractiveness of instructional media message design, Layout of learning material in Text design, Layout of learning material in design Visual / Drawing, Layout of learning material on Audio design, and Layout of learning material on Animation design. Questions of efficiency points as much as 3 pieces include the ease and speed of access by learners in the learning process, the ease and speed of access of android users, and the level of media integration as a learning tool

Questions for material experts include the contents of the AR code application media's contents using the flyer code. The validation includes aspects of effectiveness, attractiveness, and efficiency. In contrast to media experts, material experts validate the AR code application media's material using flyer code in 3-dimensional animation techniques. The validation points validate 13 questions including the accuracy and completeness of the contents of the material, improvement of learning for users when using instructional media, target information, clarity of the examples provided, ability to access learning, content of the material to the learning strategy, existence of the media towards the expression of learning content, incorporation of content text / audio / video / animation on the expression of learning content, the presence of text messages, the presence of visual / picture messages, the presence of video messages, the presence of audio messages, and the presence of animated messages. The attractiveness point validates 12 questions including the attractiveness of learning content to the desires of user groups, the convenience of user groups, the attractiveness of technology, the organization of learning media, ease of media access, ease of capturing messages by students as message users, Layout of learning materials, Layout of text, Layout of visuals / image, Video layout, Audio layout, and Animation layout. The efficiency points validate 4 questions including the speed and clarity of learning media, the ease and speed of access by learners (teachers) as users, the efficiency of technology on android, and the level of integration of the Learning Media.

Questionsfor peers and students function to get responses to media created and validated by a team of experts. A colleague is a coauthor of the teaching in the same vocational field, namely Multimedia. Consisting of 3 people with a minimum qualification of the last undergraduate education and has taught in the field of Multimedia for at least 5 years in a row. Students used as respondents were 30 active students. The student is specialized in class XI Multimedia SMK 1 Dlanggu 2019/2020 school year. Data is collected in the even semester. The author determines students of class XI Multimedia because they have studied the subject of 3-D Animation Techniques. The response was made during a trial at the development stage. Their response will be the basis for further development by the authors and the authors make a benchmark for the deployment stage. The responses of peers and students are authors arranged in the form of a questionnaire. The authors' questions were made in three categories and media experts and material experts, namely regarding effectiveness, attractiveness, and efficiency. The question consists of 10 questions consisting of 3 questions on the effectiveness aspect, 5 questions on the attractiveness aspect, and 2 questions on the efficiency aspect. The response that I want to get from peers and students is regarding the general display of learning media, visual appearance or images in each scene, display text (fonts), help improve understanding, material clarity, module clarity and Exercise questions, audio / back sound clarity sound, the existence of feedback exercises that 
exist in helping to improve understanding, the order in which the material is presented, and how the order in which the material is presented makes learning easier.

Each aspect of the effectiveness, attractiveness, and efficiency points is carried out on average as follows:

1. Each media experts and material experts

$$
\overline{\mathrm{X}}=\frac{\sum \mathrm{s}}{p}
$$

Information :

$\bar{X}=$ average score of each aspect

$\sum S=$ total score in 1 aspect

$\mathrm{p}=$ number of question

2. Peer Friends

$$
\mathrm{X}=\frac{\sum_{i=1}^{n=3} S i}{3 . p}
$$

Information :

$\bar{X} \quad=$ average score of each aspect

$\sum_{i=1}^{n=3}: \ldots:=$ number of respondents

$\mathrm{Si} \quad=$ total score in 1 aspect

$\mathrm{p}=$ number of question

3. Students

$$
\overline{\mathrm{X}}=\frac{\sum_{i=1}^{n=30} S i}{30 . p}
$$

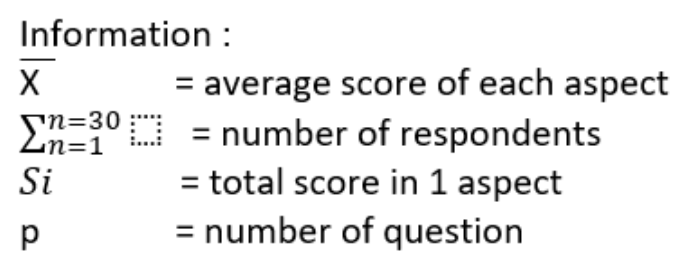

After testing the media's development, the final result is in the form of a media flyer code as a marker on the augmented realitybased apk file. Data analysis techniques using descriptive analysis. Namely in the form of descriptions not numbers. Because the data calculation is obtained in data numbers 1,2 , 3 , or 4 , conversion is needed. The author uses the average conversion of quantitative data into qualitative data developed by Sugiono (Sugiono, 2003).
Table 2 Converting Quantitative Data into Qualitative Data

\begin{tabular}{cc}
\hline Average score & Classification \\
\hline $3,50-4,00$ & Very decent \\
\hline $3,01-3,49$ & Worthy \\
\hline $2,01-3,00$ & Inadequate \\
\hline $1,00-2,00$ & Not feasible \\
\hline
\end{tabular}

\section{RESULT}

Flyer Code

AR technology, a merger between cyberspace and the real world still allows users to see the real environment. The merger will appear on the mobile screen and personal computer. Often users will be confused by which real objects and virtual objects. The uniqueness of this AR can be generated using markers. In this development study AR marker is in the form of flyer code.

Flyer code is a printed image that is easy to carry anywhere. The term "flyer" is used because the wind easily blows its lightweight form. This flyer code can be printed on a sheet of paper in various sizes. The smallest size that the application device can still recognize is $1 \mathrm{~cm} \times 1 \mathrm{~cm}$.

Each flyer codehas one complete 3-dimensional animation learning content. As is known to create a 3-dimensional animated object requires several stages. Each of these stages is modeling, rigging, animation, coloring, and texturing. Users can learn how to create 3-dimensional animated objects "rhino" by using the "rhino" flyer code. Similarly, users can learn how to create other 3-dimensional animated objects by adjusting the respective code flyer.

In a flyer code there is a picture of a particular 3-dimensional animated object, the name of the object as an explanation, and the maker's logo. The component is framed with a simple frame showing the boundary edge of a marker. Examples of flyer codes are shown in Figure 1.

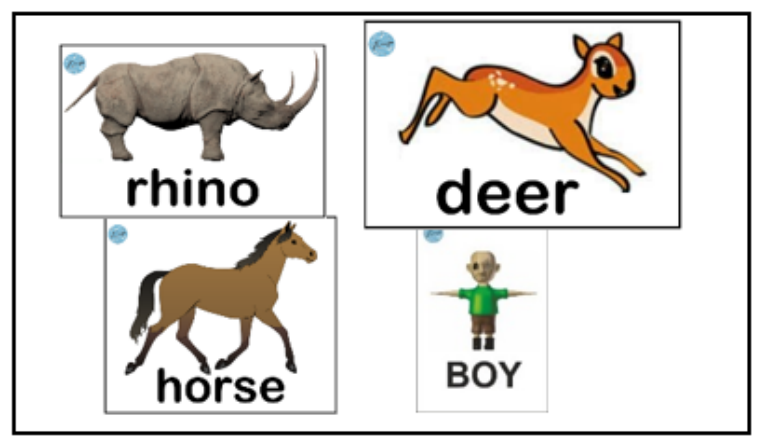

Figure 1. Flyer Code 
Making flyer code in the research of Development of Augmented Reality Code Application on 3D Animation in Learning Procedure at School is quite easy. The software used is Paint, which is Windows default software. While drawing objects can be taken from the internet or created by yourself with Drawing drawing processing software, it is even downloaded for free from the internet. The writer as a maker of learning media in schools intentionally uses software that is easily available for efficiency and effectiveness.

\section{Augmented Reality Code Application}

The working principle of the application is tracking the code on printed paper. The printed paper has a square frame with a picture of a particular object and functions as a marker. Image markers are codes for generating augmented reality objects, in this development they are called flyer codes. With a printed image code named flyer code, this augmented reality application can run. Another need is that software can build applications that can also run on mobile phones. Existing facilities such as easy to carry and move places on mobile phones will cause the software to function optimally.

Making an application is done on a computer using a Unity 3D software. One of Unity 3D's advantages is that it is open source, an interesting thing for every game developer. The use of Unity 3D as a gaming platform produces an attractive appearance and many variations. Many popular games use this software as an option in making it. Call it the Pokemon Go and Harry Potter Wizards Unite game which children and adults love. The writer appoints the software's advantages as a game developer to be a learning media developer at school.

Unity 3D software can also produce augmented reality applications. The incorporation of cyberspace into cyberspace is a major prerequisite for the use of appropriate software. With the Vuforia plugin as a marker generator which will later be used on Unity 3D. Vuforia can be downloaded for free on the internet. Identification of markers by Vuforia will get one to five stars, where five stars is a sign that the markers are very good or unique.

3-dimensional object models that appear when the flyer code is scanned with an augmented reality camera application are made using the Blender software. The selection of Blender as one of the makers of 3-dimensional objects is open source, can be downloaded for free on the internet. Objects that appear on the mobile screen are 3-dimensional objects complete with animation and texture. The 3-dimensional object is a virtual form that only appears on the screen while the surrounding environment is real.

The research of Development of Augmented Reality Code Application on 3D Animation in Learning Procedure at School contains 5 buttons as shown in Figure 2 above. 3 button contains a video tutorial which is the core of learning to make 3-dimensional objects. The contents of the learning 3D animation procedure with media Flyer Code are shown in Table 3.

Table 3. Buttons Contained in Augmented Reality Code Application

\begin{tabular}{lll}
\hline \multicolumn{1}{c}{ Button } & \multicolumn{1}{c}{ Description } & Format \\
\hline Profile & $\begin{array}{l}\text { Name and information of } \\
\text { the research maker }\end{array}$ & JPEG \\
\hline Modelling & $\begin{array}{l}\text { Video tutorial for } \\
\text { making modeling from }\end{array}$ & AVI \\
& the default object to a & \\
& 3-dimensional object & \\
\hline Rigging \& & $\begin{array}{l}\text { Video tutorial on giving } \\
\text { Animation }\end{array}$ & AVI \\
& $\begin{array}{l}\text { bone to each part and } \\
\text { sub-section and the steps } \\
\text { to do animation on each }\end{array}$ & \\
& bone & \\
\hline Coloring \& & Video tutorial for giving a & AVI \\
Texturing & surface to an object & \\
\hline Quiz & A set of questions as & TEXT \\
& a measure of material & \\
& achievement & \\
\hline
\end{tabular}

\section{D Animation Learning Procedure}

This term is usually used in the fields of art, animation, computer and mathematics. In animation such as mathematical rights, the term $X-Y$-Z is used to indicate the length, width, and height of an object. X-Y-Z often we call the coordinates. In general, 3D objects have sub objects in the form 
of elements forming these objects, in Vertex, Edge, and Face. Vertex is a point located at X-Y-Z coordinates. Merging two Vertexes will become Edge. Three Vertex and Edge formed in the surface plane in the form of a closed curve will produce a Face. A collection of Vertex, Edge, and Face will become a whole object called a Mesh. This mesh which is a 3-dimensional object, allows the object to be seen from various sides. Unlike the case with photos, even though the object taken is in the form of a real 3-dimensional object, for example, humans, but in a picture frame only 2-dimensional images will appear in the form of a field image.

3-dimensional animation is the display of sequences of images in 3D space to create motion illuminations. The distinctive feature of this type of animation affects the image to be realistic. This makes it easy for viewers to understand the object being displayed (Ahmed \& Janghel, 2015). In the research of the Development of Augmented Reality Application Code on 3D Animation in Learning Procedure at School using Blender software as a 3D modeling and animation software with the advantage of being open source and multiplatform.

Visualization of 3-dimensional objects and appear 3-dimensional on the mobile phone screen uses applications based on augmented reality, virtual reality, or mixed reality. The main reason for the application based on augmented reality is that the 3 dimensional object desired as a learning target can be seen directly by students from all desired sides, up, down, right side, left side, and every angle.

Each flyer code contains a complete package of steps to make an application, from Modeling, Rigging, Animation, Coloring, and Texturing. The AR code application using the Flyer Code as a marker is shown in Figure 2.

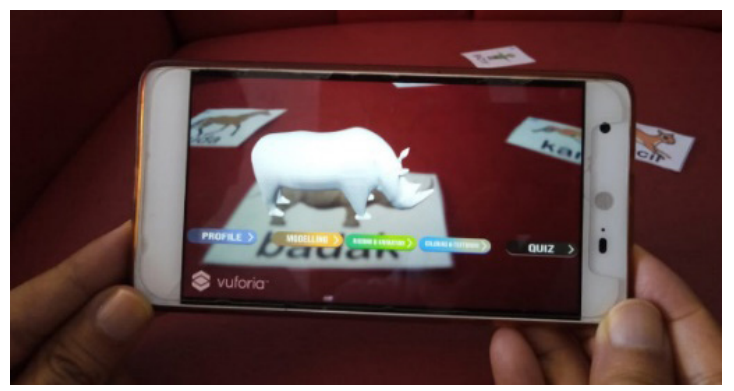

Figure 2. Demonstration of Augmented Reality Code Application

\section{Data Validity Results}

Results of the validation questionnaire data and responses obtained data results are shown with graph 1.

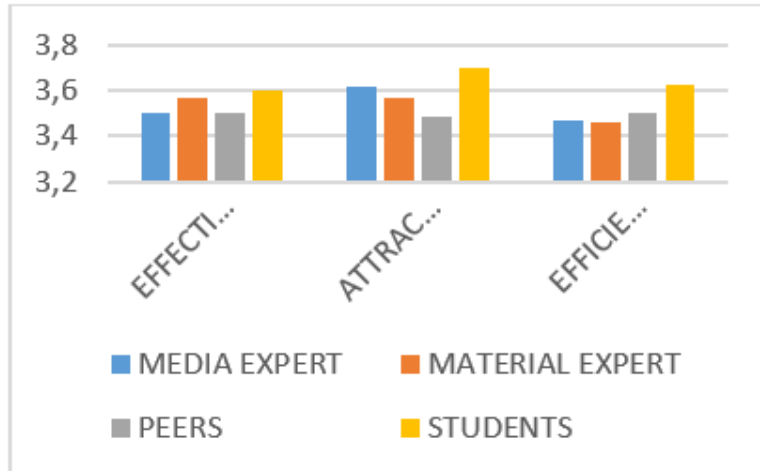

Based on the graph above, the value of the effectiveness aspect data is 3.5 for expert and peers media, 3.7 for expert material, and 3.6 for students. Whereas the attractiveness aspect is quite varied, namely 3.62 for media experts, 3.57 for material experts, 3.49 for peers, and 3.7 for students. And the last aspect of efficiency there are data results namely 3.47 for media experts, 3.46 for material experts, 3.5 for peers, and 3.63 for students

\section{DISCUSSION}

To make a media can not be directly used on students who are the object of learning, but systematic stages according to standard procedures are needed to obtain media that are truly beneficial to students themselves. The author uses the 4D development model first introduced by S. Thiagarajan (1974) as the desired stage of media development. This is according to Endang Mulyatiningsih (2011) that the 4D S. Thiagarajan development model is often used in research and development of teaching materials such as modules, worksheets, and textbooks. Not limited to that, 4D research and development models can develop other products, for example, the media (Mulyatiningsih, 2011). In his book, Sugiyono added to be able to produce certain products used research that is needs analysis and to test the effectiveness of these products to function in the wider community, research is needed to test the effectiveness of 
these products (Sugiyono, 2003). Media Flyer Code with augmented reality technology adheres to the principle of the stages in the 4D S. Thiagarajan development model systematically.

Educational technology is a field of science that tries to provide facilities or ease of learning for humans. These efforts make optimal use of learning resources through development and management functions. One of the author's facilities as a practitioner of post-Educational Technology education, trying to provide diverse and innovative facilities in the world of Education. The authors combine these innovations with the current booming trend, namely the use of android on mobile phones. AR (augmented reality) technology that was recently applied to the world of Education, the authors try to raise in development research with the title Development of Augmented Reality Application Code on 3D Animation in Learning Procedure at School.

Independent learning is a learner in this case, students who can carry out learning activities anywhere and anytime without having to face to face with the teacher or the material provider. In line with Jana Pejoska who applied distance learning to individual workers and effectively improved informal learning practices. Jana said that effective remote collaboration can enhance cooperation culture and increase knowledgesharing acquired by individuals (PejoskaLaajola, Reponen, Virnes, \& Leinonen, 2017). Likewise Straková's opinion with his research showed significant results on face-to-face learning. There is a significant difference in regular young-face learning and distance learning that gives rise to independence.

Media Flyer Code with augmented reality technology is used to increase learning activities. This is done because every child has different knowledge and skills. If only doing face-to-face learning in class, there is a possibility that the material is not absorbed equally by students. Addressing these problems the media with the concept of independent learning is used to work around this. The writer as a teacher also prepares learning tools that are suitable for his students. In educational technology, problem solving is manifested in all learning resources that are designed or selected or used for learning purposes (Najikhah, 2018).

AR technology was chosen in independent learning on the subject of 3-D Animation Engineering. And research on the development of Flyer Code media is outlined in the study of the Development of Augmented Reality Application Code on 3D Animation in Learning Procedures at School. Augmented reality technology as one of the booming technologies will be easily recognized and applied to student learning activities. Android as the largest operating system platform on mobile phones is no stranger to children today. The combination of AR and Android technology in learning becomes the basis of research. Augmented Reality Research aims to develop technology that allows realtime integration of digital content created by computers with the real world. Augmented Reality allows users to see three-dimensional virtual objects projected on the real world (Muntahanah, Toyib, \& Ansyori, 2017).This result might be explained by the fact that the components of the framework implemented in the AR applications allowed students to learn at their own pace and allowed them, in this particular learning domain of chemistry, to explore multiple possibilities for solving problems and obtain automatic feedback, which is something that is not possible to achieve directly with traditional learning materials (Acosta, Navarro, Gesa, \& Kinshuk, 2019).

Based on Yerry Soepriyanto's research in 2 studies in 2016 and 2017, Flyer Code media's development uses video embedded in augmented reality applications. Videos with sequential moving picture displays present the material for each complete 3-dimensional object creation. Video media has long been used as a learning tool and has experienced growth in various forms of delivery and the performance device (Yerry Soepriyanto, 2016). Different ways to help learn and develop skills include exploiting video with illustration techniques for the concept teaching function with real example. Thus video media can deliver abstract concept knowledge through illustrative real examples (Yerry Soepriyanto, 2017). 


\section{SUMMARY}

The visualization, which was visible on the mobile phone screen, made students excited about making 3-dimensional objects.

However, a complete reference to the stages of making 3-dimensional animated objects from the base to the complete object is almost not found for every desired object. Which is often on the internet, both youtube and free articles are human and tiger objects. While other objects, such as small children, rhinos, deer, snakes, giraffes, turtles and other animal objects are not on the internet. The average of the whole is obtained effectiveness level 3.54 with very decent, attractiveness level of 3.58 with very decent, and efficiency level 3.48 with worthy.

Learners in 3 Dimension Animation Engineering subjects require visualization of appearance that can arouse their imagination, therefore researchers try to provide solutions in the form of visualization of a 3 dimensional object and the stages of making these objects in full with augmented reality technology. This is by the objectives of developing the Development of Augmented Reality Application Code on 3D Animation in Learning Procedures at School to realize learners of 3D animation subjects, especially XI Multimedia class SMK 1 Dlanggu can learn the stages of making 3-dimensional objects independently.

\section{REFFERENCES}

Acosta, J. L. B., Navarro, S. M. B., Gesa, R. F., \& Kinshuk, K. (2019). Framework for designing motivational augmented reality applications in vocational education and training. Australasian Journal of Educational Technology, 35(3).

Aguayo, C., Cochrane, T., \& Narayan, V. (2017). Keythemes in mobile learning: Prospects for learner-generated learning through $A R$ and VR. Australasian Journal of Educational Technology, 33(6).

Ahmed, I., \& Janghel, S. (2015). 3D Animation: Don't Drink and Drive. International Journal of U-and e-Service, Science and Technology, 8(1), 415-426.

Alkhattabi, M. (2017). Augmented reality as e-learning tool in primary schools' education: Barriers to teachers' adoption. International Journal of Emerging Technologies in Learning (IJET), 12(02), 91-100.

Arief, U. M., Wibawanto, H. \& Nastiti, A.L. (2019). Membuat Game Augmented Reality (AR) dengan Unity 3D. Penerbit ANDI.

Arsyad, A. (2011). Media Pembelajaran. Jakarta: Penerbit Rajawali Pers.

Cheng, K.-H. (2017). Reading an augmented reality book: An exploration of learners' cognitive load, motivation, and attitudes. Australasian Journal of Educational Technology, 33(4).

Cochrane, T., Cook, S., Aiello, S., Christie, D., Sinfield, D., Steagall, M., and Aguayo, C. (2017). A DBR framework for designing mobile virtual reality learning environments. Australasian Journal of Educational Technology, 2017, 33(6).

Knight, J., \& Barbera, E. (2018). Navigational Acts and Discourse: Fostering Learner Agency in Computer-Assisted Language Learning. Electronic Journal of E-Learning, 16(1), 67-76.

Mantasia, M., \& Jaya, H. (2016). Pengembangan teknologi augmented reality sebagai penguatan dan penunjang metode pembelajaran di SMK untuk implementasi Kurikulum 2013. Jurnal Pendidikan Vokasi, 6(3), 281-291.

Mulyatiningsih, E. (2011). Riset terapan bidang pendidikan dan teknik. Yogyakarta: UNY Press.

Muntahanah, M., Toyib, R., \& Ansyori, M. (2017). Penerapan Teknologi Augmented Reality Pada Katalog Rumah Berbasis Android (Studi Kasus Pt. Jashando Han Saputra). Pseudocode, 4(1), 81-89.

Najikhah, F. (2018). Pengembangan Buku Panduan Sebagai Sumber Belajar Untuk Tenaga Kerja Indonesia Di Malaysia. Edcomtech Jurnal Kajian Teknologi Pendidikan, 3(2), 75-86.

Pamoedji, A. K. \& Maryuni, R. S. (2017). Mudah Membuat Game Augmented Reality (AR) dan Virtual Reality (VR) dengan Unity 3D. Elex Media Komputindo.

Pejoska-Laajola, J., Reponen, S., Virnes, M., \& Leinonen, T. (2017). Mobile augmented 
communication for remote collaboration in a physical work context. Australasian Journal of Educational Technology, 33(6).

Peraturan Pemerintah Nomor 66 tahun 2013 Tentang Standart Penilaian Pendidikan.

Permendikbud Nomor 65 Tahun 2013 Tentang Besar Standar Proses Pendidikan Dasar dan Menengah

Putra, N. (2011). Research \& Development Penelitian dan Pengembangan: Suatu Pengantar. Jakarta: Penerbit Raja Grafindo Persada.

Sanjaya, W. (2010). Strategi Pembelajaran Berorientasi Standar Proses Pendidikan. Jakarta: Kencana

Soepriyanto, Y., Sulthoni, S., \& Ulfa, S. (2017). Pengembangan Augmented Reality Sebagai Electronic Performance Support System Dalam Pembelajaran. Edcomtech Jurnal Kajian Teknologi Pendidikan, 2(1), 1-10.

Soepriyanto, Y., \& Rahmatullah, B. (2017). Pengembangan Video Termediasikan Augmented Reality sebagai Electronic Performance Support System dalam Pembelajaran. Edcomtech Jurnal Kajian
Teknologi Pendidikan, 1(2), 111-117.

Straková, Z., and Cimermanová, I. (2018). Developing Reflective Skills of Student Teachers in the Virtual Learning Environment. The Electronic Journal of e-Learning, 16(2), 107-121

Sugiyono. (2003). Metode Penelitian Administrasi Dilengkapi dengan Metode R\&D. Bandung: CV. AFABETA

Tan, Q., \& Chang, W. (2015). Location-Based Augmented Reality for Mobile Learning: Algorithm, System, and Implementation. Electronic Journal of e-Learning, 13(2), 138-148.

Thiagaran, S. Semmel, Dorothy S, Semmel, Melvyn I. (1974). Intructional development for training teacher of exeptional children. Minesota: The Council for Exepttional Children.

Tim Pascasarjana UNESA. (2014). Panduan Penulisan Tesis dan Desertasi Program Program Pascasarjana Unesa. Surabaya: Univercity Press.

Undang - Undang Nomor 20 Tahun 2003. Sistem Pendidikan Nasional. 